\title{
Synthesis of $\alpha$-Iodoketones from Allylic Alcohols through Aerobic Oxidative Iodination
}

\author{
Amparo Sanz-Marco, ${ }^{\text {a }}$ Štefan Možina, ${ }^{\text {b,c }}$ Jernej Iskra, ${ }^{\text {de* } *}$ and Belén Martín-Matute ${ }^{a *}$ \\ a Department of Organic Chemistry, Stockholm University, Stockholm 10691, Sweden \\ +468162438, E-mail: belen.martin.matute@su.se \\ b Centre of Excellence for Integrated Approaches in Chemistry and Biology of Proteins, Jamova 39, Ljubljana, Slovenia \\ Jožef Stefan International Postgraduate School, Jamova 39, Ljubljana, Slovenia. \\ d Department of Physical and Organic Chemistry, Jamova 39, Ljubljana, Slovenia. \\ e Faculty of Chemistry and Chemical Technology, University of Ljubljana, Večna pot 113, 1000 Ljubljana, Slovenia. \\ E-mail: Jernej.Iskra@fkkt.uni-lj.si
}

Received: ((will be filled in by the editorial staff))

Supporting information for this article is available on the WWW under http://dx.doi.org/10.1002/adsc.201\#\#\#\#\#\#.

\begin{abstract}
An efficient method for the synthesis of $\alpha$ iodoketones from allylic alcohols and elemental iodine is reported. We show in this paper that the isomerization of allylic alcohols catalyzed by iridium(III) complexes can be combined with an aerobic oxidative iodination protocol, resulting in a straightforward method for the synthesis of a wide range of $\alpha$-iodoketones as single constitutional isomers and in high yields under mild reaction conditions.
\end{abstract}

Keywords: isomerization; aerobic oxidative iodination; $\alpha$ iodoketones; $\alpha$-aminoketones; allylic alcohol
Iodine is often found in molecules with important applications in industrial and medicinal chemistry. ${ }^{[1]}$ Iodinated organic compounds also play a pivotal role in synthetic organic chemistry as versatile building blocks, as reflected by the vast number of derivatization procedures that have been reported in the literature. ${ }^{[2]}$ At present, numerous methods are known for the synthesis of $\alpha$-iodinated carbonyl compounds starting from esters, ${ }^{[3]}$ ketones, ${ }^{[4]}$ and even amides. ${ }^{[5]}$ When it comes to the synthesis of $\alpha$ iodoketones, most of the reported methods rely on the reaction of preformed enol or enolate derivatives with electrophilic iodinating agents. This approach works well when applied to ketones with only one type of enolizables carbon, such as aryl or symmetrical aliphatic ketones. From ketones with two enolizable $\alpha$ carbons having a strong electronic or steric bias, excellent regiocontrol can be achieved, although often only one regiochemical outcome is viable. In most instances, however, mixtures of both regioisomers are generally obtained, leading to low yields and difficult purifications (Scheme 1a). ${ }^{[4 c, d]}$

Recently, an article from one of our laboratories described an alternative procedure for the preparation of $\alpha$-iodinated ketones as single constitutional isomers, starting from allylic alcohols (Scheme 1b). ${ }^{[6]}$ The method relies on a 1,3-hydrogen shift catalyzed by an $\operatorname{Ir}(\mathrm{III})$ complex, carried out in the presence of an electrophilic iodinating agent. This protocol gave access to $\alpha$-iodinated carbonyl compounds formally derived from unsymmetrical aliphatic ketones in excellent yields for the first time. A key aspect for obtaining high yields and minimizing unwanted iodination side reactions was the use of a new mild

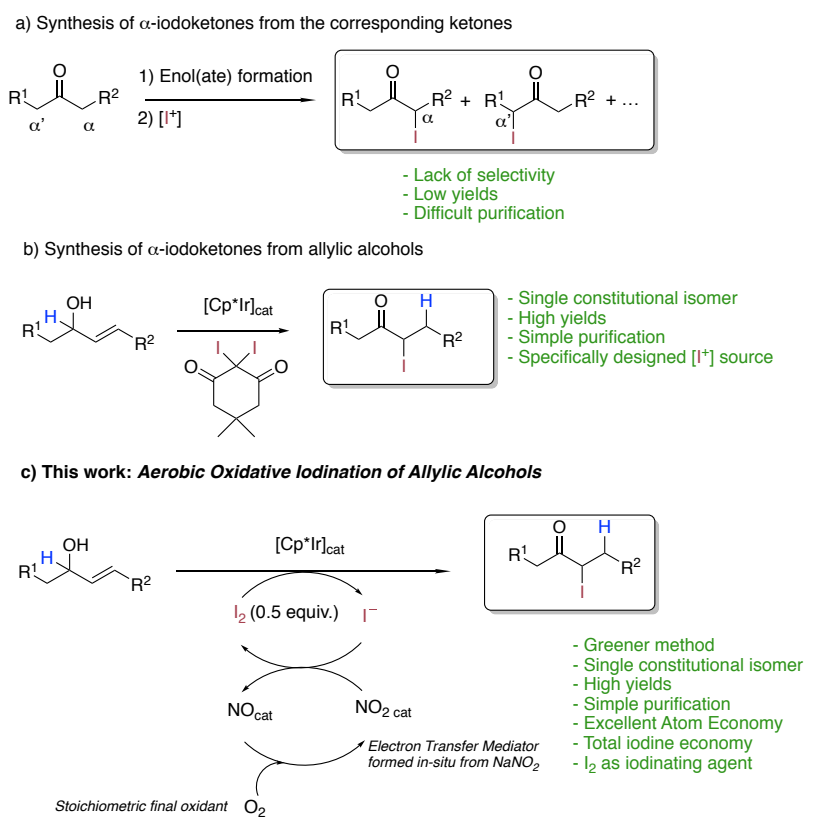

Scheme 1. Synthesis of $\alpha$-Iodoketones. 
iodinating

agent, dimethylcyclohexane-1,3-dione (Scheme 1b).

Commercially available and commonly used electrophilic iodinating agents such as $\mathrm{I}_{2}, \mathrm{ICl}$, or NIS ( $N$-iodosuccinimide) failed to give the desired product in reasonable yield. Among these electrophilic agents, $\mathrm{I}_{2}$ would be the most convenient option, as it has a very low toxicity, is environmentally friendly and a cheap and commercially available reagent. From an atomeconomy point of view, $I_{2}$ is also the best alternative. ${ }^{[7]}$

In electrophilic monoiodination reactions that use $\mathrm{I}_{2}$ as the halogen source, only one of the two halogen atoms can be used as electrophile $\left(\mathrm{I}^{+}\right)$; one equivalent of iodide $\left(\mathrm{I}^{-}\right)$is formed as a by-product. The halogen atom economy can be improved through the addition of an oxidant to the reaction mixture to oxidize the iodide formed. Several oxidants, have been used in oxidative iodinations in stoichiometric amounts; ${ }^{[8]}$ these include $\mathrm{MnO}_{2}{ }^{[8 \mathrm{ff}]}$ hypervalent iodine compounds, ${ }^{[8 c, d, h]} \mathrm{CuO},{ }^{[8 b]}$ oxone, ${ }^{[81]}$ and $\mathrm{H}_{2} \mathrm{O}_{2} \cdot{ }^{\left[{ }^{[8,}, \mathrm{i}, \mathrm{j}\right]}$ One of us has described the aerobic oxidative iodination of organic molecules in excellent yields, using elemental iodine together with oxygen or air as the stoichiometric oxidant. ${ }^{[9]}$ The process requires the use of catalytic amounts of $\mathrm{NaNO}_{2}$ as an electron-transfer mediator, and acidic conditions, and therefore involves nitrogen oxide intermediates. Although oxidative iodination protocol has been used for the $\alpha$-iodination of ketones, no regiocontrol was achieved for unbiased unsymmetrical ketones (Scheme 1a). ${ }^{[8 c, e],[9 b, c]}$

In this paper, we report the synthesis of $\alpha$ iodoketones as single constitutional isomers from readily available allylic alcohols. The method combines a 1,3-hydrogen shift mediated by iridium(III) catalysts with a C-I bond formation using 0.5 equivalents of iodine as the halogen source under aerobic oxidative conditions (Scheme 1c).

As a starting point to study this transformation, we chose to test the reaction conditions reported by one of $\mathrm{us}^{[\mathrm{gd}]}$ for oxidative iodination, i.e., $\mathrm{I}_{2}(0.5$ equiv. $)$ and $\mathrm{NaNO}_{2}(5 \mathrm{~mol} \%)$ and applied them to allylic alcohol 1a (Table 1). First, we tested several iridium catalysts of the general structure $[\mathrm{Cp} * \operatorname{Ir}(\mathrm{III})]$, that we used successfully in the halogenation of allylic alcohols, and in the isomerization of allylic alcohols into carbonyl compounds in a mixture of THF and $\mathrm{H}_{2} \mathrm{O}$ $(3: 1){ }^{[10,11]}$ Catalysts II and III showed similar activities, higher to that of $\operatorname{Ir}(\mathrm{III})$ chloride complex $\mathbf{I}$. $\alpha$-Iodoketone 2a was formed in all cases, in yields ranging from 47 to $60 \%$. An important challenge of this chemistry is to minimize the formation of enone by-products, formed by direct oxidation of the allylic alcohols. For the three catalysts screened, only up to $8 \%$ of enone 3 was produced (Table 1, entries 1-3). Complex II $\left(\left[\mathrm{Cp}^{*} \operatorname{Ir}\left(\mathrm{H}_{2} \mathrm{O}\right)_{3}\right] \mathrm{SO}_{4}\right)$ was chosen to continue the optimization studies. Higher yields of $\mathbf{2 a}$ were obtained when the reaction was run under an atmosphere of $\mathrm{O}_{2}(70 v s 60 \%$, entry 4 vs entry 2$)$.
Interestingly, this change also inhibited the formation of enone $\mathbf{3}$ (entry 4 ). When the reaction was carried out in a mixture of 2-methyltetrahydrofuran (2-MeTHF) and $\mathrm{H}_{2} \mathrm{O}$ in a $3: 1$ ratio, 2 a was obtained in $72 \%$ yield (entry 5). When a mixture of acetone and $\mathrm{H}_{2} \mathrm{O}(3: 1)$ was used, 2a was formed in only $13 \%$ yield (entry 6 ). 2-MeTHF/ $\mathrm{H}_{2} \mathrm{O}$ was chosen as the optimal solvent mixture being 2-MeTHF an ecofriendly alternative to THF. ${ }^{[12]}$ Upon dilution of the reaction mixture $(0.04 \mathrm{M}$ vs $0.2 \mathrm{M}$ ), the yield of $\mathbf{2 a}$ increased further to $90 \%$ (entry 7). Control experiments were also carried out (entries 8-11). Both catalysts, iridium complex II and $\mathrm{NaNO}_{2}$, were found to be essential for the formation of the desired product (entries 8 and 9, respectively). Replacement of $\mathrm{I}_{2}$ by NIS or KI under otherwise identical reaction conditions did not give the product either (entries 10-11). The reaction conditions of entry 7 were chosen as the optimal conditions for studying the substrate scope, i.e., 0.5 equiv. of $\mathrm{I}_{2}, 5 \mathrm{~mol} \%$ of $\mathrm{NaNO}_{2}$, and $2 \mathrm{~mol} \%$ of iridium complex II. Remarkably, oxidation by-products, such as enone 3, were not observed under these reaction conditions.

Table 1. Optimization of the reaction conditions.

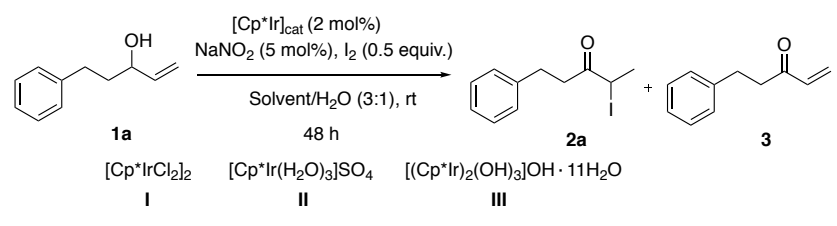

\begin{tabular}{lllll}
\hline Entry $^{[\mathrm{a}]}$ & {$\left[\mathrm{Cp}{ }^{*} \mathrm{Ir}\right]$} & atm. & Solvent $/ \mathrm{H}_{2} \mathrm{O}$ & $\begin{array}{l}\mathbf{2 a} / \mathbf{3} \\
(\%))^{[\mathrm{b}]}\end{array}$ \\
\hline 1 & I & Air & $\mathrm{THF} / \mathrm{H}_{2} \mathrm{O}$ & $47 / 8$ \\
2 & II & $\mathrm{Air}$ & $\mathrm{THF} / \mathrm{H}_{2} \mathrm{O}$ & $60 / 8$ \\
3 & III & $\mathrm{Air}$ & $\mathrm{THF} / \mathrm{H}_{2} \mathrm{O}$ & $60 / 8$ \\
4 & II & $\mathrm{O}_{2}$ & $\mathrm{THF} / \mathrm{H}_{2} \mathrm{O}$ & $70 /-$ \\
5 & II & $\mathrm{O}_{2}$ & $2-\mathrm{MeTHF} / \mathrm{H}_{2} \mathrm{O}$ & $72 /-$ \\
6 & II & $\mathrm{O}_{2}$ & Acetone $/ \mathrm{H}_{2} \mathrm{O}$ & $13 / 7$ \\
$7^{[\mathrm{c}]}$ & II & $\mathrm{O}_{2}$ & $2-\mathrm{MeTHF} / \mathrm{H}_{2} \mathrm{O}$ & $90 /-$ \\
$8^{[\mathrm{c}]}$ & - & $\mathrm{O}_{2}$ & $2-\mathrm{MeTHF} / \mathrm{H}_{2} \mathrm{O}$ & - \\
$9^{[\mathrm{c}],[\mathrm{d}]}$ & II & $\mathrm{O}_{2}$ & $2-\mathrm{MeTHF} / \mathrm{H}_{2} \mathrm{O}$ & $32 /-$ \\
$10^{[\mathrm{c}],[\mathrm{e}]}$ & II & $\mathrm{O}_{2}$ & $2-\mathrm{MeTHF} / \mathrm{H}_{2} \mathrm{O}$ & - \\
$11^{[\mathrm{c}],[\mathrm{f}]}$ & II & $\mathrm{O}_{2}$ & $2-\mathrm{MeTHF} / \mathrm{H}_{2} \mathrm{O}$ & - \\
\hline
\end{tabular}

[a] Unless otherwise noted, 1a $(0.2 \mathrm{mmol})$, solvent $/ \mathrm{H}_{2} \mathrm{O}$ (0.2 M, (3:1)), [Ir] (2 mol\%), $\mathrm{NaNO}_{2}(5 \mathrm{~mol} \%), \mathrm{I}_{2}(0.5$ equiv.) were used. [b] Yield determined by ${ }^{1} \mathrm{H}$ NMR spectroscopy against an internal standard. [c] $0.04 \mathrm{M}$. [d] Without $\mathrm{NaNO}_{2}$. [e] NIS instead of $\mathrm{I}_{2}$; a mixture of unknown byproducts was observed. [f] KI instead of $\mathrm{I}_{2}$; after $48 \mathrm{~h}$, only starting material was observed.

Having established these optimal conditions, the substrate scope was investigated (Scheme 2). Aliphatic allylic alcohols bearing terminal alkenes (2a-2c) gave the desired $\alpha$-iodoketones in high yields (89-99\%). Aromatic allylic alcohols (2d-2e) were also well tolerated. Additional functional groups in the allylic alcohols, such as benzyl-protected alcohols, additional double bonds, and silyl ethers, were well tolerated, and the corresponding $\alpha$-iodinated products 
were formed in high yields (2g-2i). Allylic alcohols bearing internal alkenes $(\mathbf{2} \mathbf{j}-\mathbf{2} \mathbf{m})$ provided the desired products in moderate to good yields (40-75\%). Finally, $\alpha$-iodinated aldehydes were obtained in good yields when primary allylic alcohols were subjected to the reaction conditions $(\mathbf{2 n - 2 p})$. In all instances, $\mathbf{2}$ obtained as single constitutional isomers.

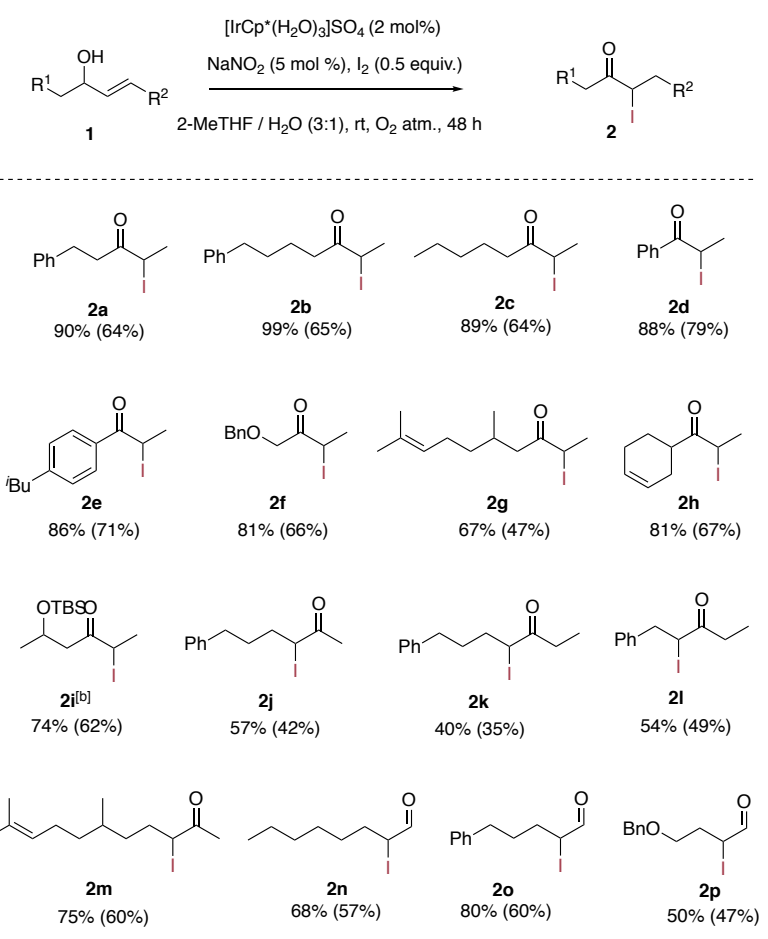

Scheme 2. Substrate scope. Yield determined by ${ }^{1} \mathrm{H}$ NMR spectroscopy against an internal standard. Isolated yields in parentheses. [b] TBS = tert-butyldimethylsilyl.

Remarkably, the reactions were carried out using only $5 \mathrm{~mol} \%$ of $\mathrm{NaNO}_{2}$ and 0.5 equiv. of $\mathrm{I}_{2}$, and, in contrast to our previous reports, ${ }^{[9]}$ in the absence of an acid additive. A proposed mechanism is shown in Scheme 3. The reaction of the allylic alcohol with the iridium catalyst ${ }^{[11,13]}$ and molecular iodine gives the corresponding $\alpha$-iodoketone. ${ }^{[6,10]} \mathrm{HI}$ is formed as a byproduct, which in turn protonates $\mathrm{NaNO}_{2}$ to give nitrous acid. Rapid decomposition of $\mathrm{HNO}_{2}$ gives $\mathrm{NO}_{2}$, a good oxidant that acts as an electron-transfer mediator in the oxidation of iodide by oxygen, the stoichiometric oxidant. ${ }^{[9 \mathrm{~d}]}$

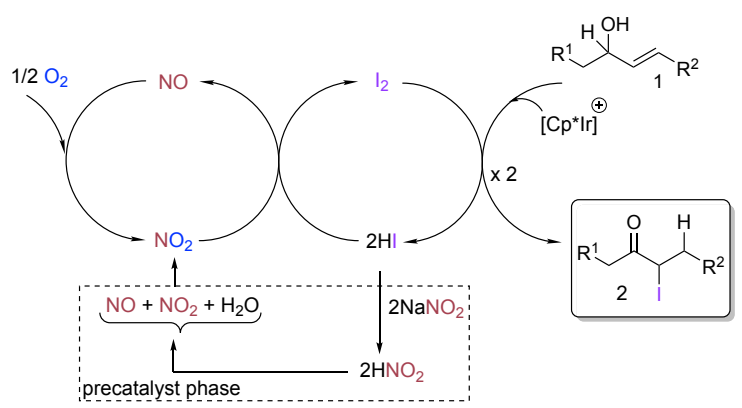

Scheme 3. Proposed mechanism.
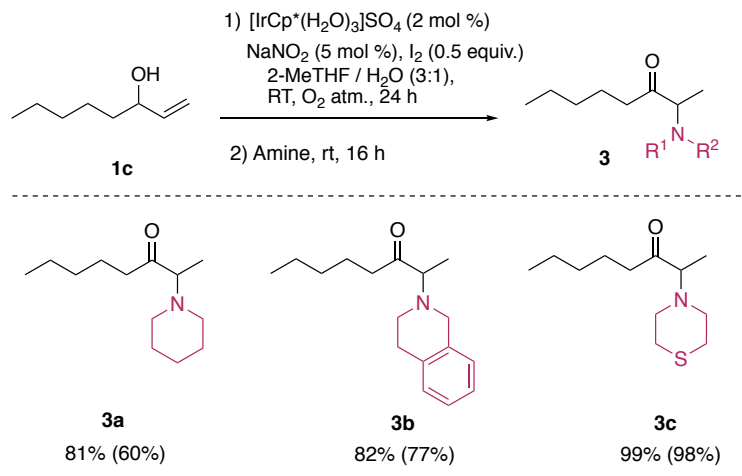

Scheme 4. Synthesis of $\alpha$-aminoketones. Yield determined by ${ }^{1} \mathrm{H}$ NMR spectroscopy against an internal

The synthetic utility of this new method was demonstrated by taking advantage of the reactivity of $\alpha$-iodoketones with nitrogen nucleophiles. Thus, $\alpha$ aminoketones (3a-3c) were prepared from allylic alcohol 1c in a one-pot two-step procedure (Scheme 4). Since $\alpha$-aminoketones 3a-3c are formally derived from unsymmetrical aliphatic ketones (i.e., with unbiased enolizable methylene groups), their direct preparation from these precursors would result in the formation of mixtures of $\alpha$ - and $\alpha$ '-aminoketones. In contrast, the synthetic route shown in Scheme 4 yields these compounds as single constitutional isomers in excellent yields $(99-81 \%)$.

In conclusion, we have described the synthesis of $\alpha$ iodoketones from the corresponding allylic alcohols and molecular iodine. The method relies on an $\operatorname{Ir}(\mathrm{III})-$ catalyzed 1,3-hydrogen shift followed by an aerobic oxidative iodination. The reaction uses just 0.5 equivalents of molecular iodine, in combination with $\mathrm{NaNO} 2$ as oxidation catalyst and oxygen as the final terminal oxidant. A wide range of $\alpha$-iodocarbonyl compounds have been synthesized, all as single constitutional isomers. A one-pot procedure for the transformation of allylic alcohols into $\alpha$-aminoketones has also been developed.

\section{Experimental Section}

General procedure for the synthesis of $\alpha$-iodoketones from allylic alcohols: In a pressure tube, $\mathrm{NaNO}_{2}(0.7 \mathrm{mg}$, $0.01 \mathrm{mmol}, 5 \mathrm{~mol} \%)$, [Cp* $\left.\operatorname{Ir}\left(\mathrm{H}_{2} \mathrm{O}\right)_{3}\right] \mathrm{SO}_{4}(2 \mathrm{mg}, 0.004 \mathrm{mmol}$, $2 \mathrm{~mol} \%$ ) and $\mathrm{I}_{2}(25.3 \mathrm{mg}, 0.1 \mathrm{mmol}, 0.5$ equiv.) were added.' The tube was sealed with a Teflon lined cap and the allylic alcohol $1(0.2 \mathrm{mmol})$ dissolved in 2-MeTHF $(3.75 \mathrm{~mL})$ and $\mathrm{H}_{2} \mathrm{O}(1.25 \mathrm{~mL})$ was added to the mixture. The pressure tube was purged with oxygen $(1 \mathrm{~atm})$ and kept under oxygen (1 atm) by using a balloon. The reaction was stirred at room temperature for $48 \mathrm{~h}$, and subsequently quenched with an aqueous solution of $\mathrm{Na}_{2} \mathrm{~S}_{2} \mathrm{O}_{3}(1.5 \mathrm{~mL})$ and extracted with $\mathrm{Et}_{2} \mathrm{O}(3 \times 2 \mathrm{~mL})$. The combined organic phases were dried over $\mathrm{MgSO}_{4}$ and the solvent was reduced under pressure. The final product was purified by column chromatography using petroleum ether / EtOAc (99:1) mixture as eluent.

General procedure for the synthesis of $\boldsymbol{\alpha}$-aminoketones from allylic alcohols: In a pressure tube, $\mathrm{NaNO}_{2}(0.7 \mathrm{mg}$, $0.01 \mathrm{mmol}, 5 \mathrm{~mol} \%)$, [Cp* $\left.\operatorname{Ir}\left(\mathrm{H}_{2} \mathrm{O}\right)_{3}\right] \mathrm{SO}_{4}(2 \mathrm{mg}, 0.004 \mathrm{mmol}$, $2 \mathrm{~mol} \%)$ and $\mathrm{I}_{2}(25.3 \mathrm{mg}, 0.1 \mathrm{mmol}, 0.5$ equiv.) were added. The tube was sealed with a Teflon lined cap and the allylic alcohol 1c (26 mg, $0.2 \mathrm{mmol})$ dissolved in 2-MeTHF (3.75 
$\mathrm{mL})$ and $\mathrm{H}_{2} \mathrm{O}(1.25 \mathrm{~mL})$ was added to the mixture. The pressure tube was purged with oxygen $(1 \mathrm{~atm})$ and kept under oxygen (1 atm) by using a balloon. The reaction was stirred at room temperature for $24 \mathrm{~h}$, and the corresponding amine $(0.3 \mathrm{mmol})$ was added. The mixture was stirred $16 \mathrm{~h}$ under air atm. and subsequently quenched with an aqueous solution of $\mathrm{Na}_{2} \mathrm{~S}_{2} \mathrm{O}_{3}(1.5 \mathrm{~mL})$ and extracted with $\mathrm{Et}_{2} \mathrm{O}(3 \mathrm{x}$ $2 \mathrm{~mL}$ ). The combined organic phases were dried over $\mathrm{MgSO}_{4}$ and the solvent was reduced under pressure. The final product was purified by column chromatography using petroleum ether / EtOAc (9:1) mixture as eluent.

\section{Acknowledgements}

[1] T. Kaiho in Industrial application of iodine in Iodine Chemistry and Applications, (Eds.; John Wiley \& Sons), New Jersey, 2015, pp 457-554 and pp 353-456.

[2] a) L. Herrera, P. Barrio, I. Ibáñez, R. Román, N. Mateu and S. Fustero, Org. Lett. 2016, 18, 4722-4725; b) L. Lafferentz, V. Eberhardt, C. Dri, C. Africh, G. Comelli, F. Esch, S. Hecht and L. Grill, Nature Chem. 2012, 4, 215-220.

[3] a) B. Sreedhar, P. Surendra Reddy and M. Madhavi, Synthetic Commun. 2007, 37, 4149-4156; b) J. C. Lee, J. Y. Park, S. Y. Yoon, Y. H. Bae and S. J. Lee, Tetrahedron Lett. 2004, 45, 191-193; c) J. C. Lee and Y. H. Bae, Synlett 2003, 507-508.

[4] a) I. Pravst, M. Zupan and S. Stavber, Tetrahedron 2008, 64, 5191-5199; b) H. M. Meshram, P. N. Reddy, P. Vishnu, K. Sadashiv and J. S. Yadav, Tetrahedron Lett. 2006, 47, 991-995; c) M. L. N. Rao and D. N. Jadhav, Tetrahedron Lett. 2006, 47, 6883-6886; d) J. Barluenga, M. Marco-Arias, F. González-Bobes, A. Ballesteros and J. M. González, Chem. Commun. 2004, 2616-2617.

[5] a) O. Kitagawa, N. Kikuchi, T. Hanano, K. Aoki, T. Yamazaki, M. Okada and T. Tawchi, J. Org. Chem. 1995, 60, 7161-7165; b) A. O. King, R. K. Anderson, R. F. Shuman, S. Karady, N. L. Abramson and A. W. Douglas, J. Org. Chem. 1993, 58, 3384-3386.

[6] S. Martinez-Erro, A. Bermejo Gómez, A. VázquezRomero, E. Erbing and B. Martín-Matute, Chem. Commun. 2017, 53, 9842-9845.

[7] a) D. T. Racys, S. A. I. Sharif, S. L. Pimlott and A. Sutherland, J. Org. Chem. 2016, 81, 772-780; b) L. T. C. Crespo, R. da S. Ribeiro, M. C. S. de Mattos and P. M. Esteves, Synthesis 2010, 14, 2379-2383; c) J. Barluenga, J. M. González, M. A. G. Martín, P. J. Campos and G. Asensio, J. Org. Chem. 1993, 58, 2058-2060.

[8] a) H. Cao, J. Yuan, C. Liu, X. Hu and A. Lei, RSC Adv. 2015, 5, 41493-41496; b) M. Gao, Y. Yang, Y.-D. Wu, C. Deng, L.-P. Cao, X.-G. Meng and A.-X. Wu, Org. Lett. 2010, 12, 1856-1859; c) S. Yusubov, R. Y. Yusubova, T. V. Funk, K.-W. Chi, A. Kirschning and V. Zhdankin, Synthesis 2010, 21, 3681-3685; d) J. N. Moorthy, K. Senapati and S. Kumar, J. Org. Chem. 2009, 74, 6287-6290; e) M. Jereb, J. Iskra, M. Zupan and S. Stavber, Lett. Org. Chem. 2005, 2, 465-468; f) G. Le Bras, O. Provot, A. Bekaert, J.-F. Peyrat, M. Alami and J.-D. Brion, Synthesis 2006, 9, 1537-1544; g) J. Iskra, S. Stavber and M. Zupan, Synthesis 2004, 1869-1873; h) A. R. De Corso, B. Panunzi and M. Tingoli, Tetrahedron Lett. 2001, 42, 7245-7247; i) L. Bedrač and J. Iskra, $A d v$.
This project was supported by the Swedish Research Council through Vetenskapsradet and Formas, and also by the Knut and Alice Wallenberg Foundation, and the Slovenian Research Agency (P1- 0134 and MR 36492, ARRS-SP-2990/17). A. S.-M. was supported by the Generalitat Valenciana, the European Social Fund and Universitat de València (Spain) through a postdoctoral grant. S. M. was supported by COST Action CM1205 CARISMA (Catalytic Routines for Small Molecule Activation) and an AdFutura grant. We also thank $\mathrm{Dr}$ A. Bermejo Gómez for helpful discussions.

\section{References}

Synth. Catal. 2013, 355, 1243-1248; j) Review: A. Podgoršek, M. Zupan and J. Iskra, Agnew. Chem. Int. Ed. 2009, 48, 8424-8450; k) M. A. Khalilzadeh, A. Hosseini, M. Shokrollahzadeh, M. R. Halvagar, D. Ahmadi, F. Mohannazadeh, M. Tajbakhsha Tetrahedron Lett. 2006, 47, 3525-3528; 1) M. M. Reddy, M. A. Kumar, P. Swamy, N. Narender Tetrahedron Lett. 2011, 52, 6554-6559; m) R. Prebil, S. Stavber Tetrahedron Lett. 2014, 55, 5643-5647; n) J. Zhang, S. Li, G.-J. Deng, H. Gong ChemCatChem 2018, 10, 376-380.

[9] a) J. Iskra and S. S. Murphree, Tetrahedron Lett. 2017, 58, 645-648; b) G. Stavber, J. Iskra, M. Zupan and S. Stavber, Green Chem. 2009, 11, 1262-1267; c) G. Stavber, J. Iskra, M. Zupan and S. Stavber, Adv. Synth. Catal. 2008, 350, 2921-2929; d) J. Iskra, S. Stavber, M. Zupan, Tetrahedron Lett. 2008, 49, 893-895.

[10] a) N. Ahlsten and B. Martín-Matute, Chem. Commun. 2011, 47, 8331-8333; b) N. Ahlsten, A. Bermejo Gómez and B. Martín-Matute, Angew. Chem. 2013, 125, 6393-6396; Angew. Chem. Int. Ed. 2013, 52, 6273-6276; c) A. Bermejo Gómez, E. Erbing, M. Batuecas, A. Vázquez-Romero and B. Martín-Matute, Chem. Eur. J. 2014, 20, 10703-10709; (d) A. VázquezRomero, A. Bermejo Gómez and B. Martín-Matute, ACS Catal. 2015, 5, 708-714.

[11] E. Erbing, A. Vázquez-Romero, A. Bermejo Gómez, A. E. Platero-Prats, F. Carson, X. Zou, P. Tolstoy, B. Martín-Matute, Chem. Eur. J. 2016, 22, 15659-15663.

[12] a) V. Pace, P. Hoyos, M. Fernandez, J. V. Sinisterra and A. R. Alcántara, Green Chem. 2010, 12, 1380-1382; b) Review: V. Pace, P. Hoyos, L. Castoldi, P. Domínguez de Mara, and A. R. Alcántara, ChemSusChem 2012, 5, 1369-1379.

[13] Mechanistic proposals on the transition-metalcatalyzed isomerization of allylic alcohols, see: a) V. Cadierno, S. E. Garcia-Garrido, J. Gimeno, A. VarelaÁlvarez, J. A. Sordo, J. Am. Chem. Soc. 2006, 128, 1360-1370; b) A. Varela-Álvarez, J. A. Sordo, E. Piedra, N. Nebra, V. Cadierno, J. Gimeno, Chem. Eur. J. 2011, 17, 10583-10599; c) L. Bellarosa, J. Díez, A. Lledós, F. J. Suárez, G. Ujaque, C. Vicent, Chem. Eur. J. 2012, 18, 7749-7765; d) S. Manzini, A. Poater, D. J. Nelson, L. Cavallo, S. P. Nolan, Chem. Sci. 2014, 5, 180-188; Reviews: e) N. Ahlsten, A. Bartoszewicz, B. MartínMatute, Dalton Trans. 2012, 41, 1660-1670; f) P. Lorenzo-Luis, A. Romerosa, M. Serrano-Ruiz, ACS Catal. 2012, 2, 1079-1086; g) D. Cahard, S. Gaillard, J.L. Renaud, Tetrahedron Lett. 2015, 56, 6159-6169. 
